\title{
Perception on Usability and Risk of E-Business Platform for Women Managed Small and Medium Weaving Enterprises
}

\section{Gusti Ayu Purnamawati ${ }^{*}$, I Gusti Bagus Baskara Nugraha2}

${ }^{1}$ Faculty of Economic, Universitas Pendidikan Ganesha, Singaraja, Indonesia

${ }^{2}$ School of Electrical and Informatics Engineering, Institut Teknologi Bandung, Bandung, Indonesia

\section{ART I CLE IN F O}

\section{Article history:}

Received August 19,202

Revised Auguts 20, 2021

Accepted October 01, 2021

Available online November 25, 2021

Keywords:

E-Business, Risk, Smes, Weaving

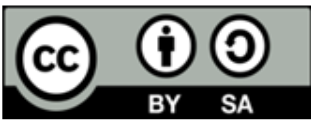

This is an open access article under the CC BY-SA license.

Copyright $(2021$ by Author. Published by Universitas Pendidikan Ganesha.

\section{A B S T R A C T}

Rapid technological advances in information and communication technology have resulted in distance no longer a major problem in conducting business activities. Every individual and business actor is also carried away by the flow of having tools that can support their daily activities have been parts of the existence of technology. This study analyzes the effect of usability and risk perception in small and medium weaving enterprises (SMWE), which women manage, in using e-business, e.g., online shops, e-commerce, and marketplaces. We surveyed 43 SMWEs using questionnaires and interviews and selected the samples using the saturated sampling technique. Quantitative data was collected through a Likert scale and then analyzed using multiple linear regression. The study results show that usability positively affects the interest in using e-business in SMWEs. Meanwhile, the risk perception variable has a negative and significant direction. Usability makes it easier for individuals to understand and easy to get information in using e-business. The use of information systems can speed up work and provide flexibility in convenience. The risks faced by ebusiness users are transaction security and the uncertainty of the goods ordered. Perceived risk will hurt the individual's intention to use the online store. This prediction arises based on logic if the higher risk on online transactions lacks necessary trust.

\section{INTRODUCTION}

Rapid technological advances in information and communication technology have resulted in distance no longer a major problem in conducting business activities. Every individual and business actor is also carried away by the flow of having tools that can support their daily activities have been parts of the existence of technology. Technological developments have shifted the pattern of life, especially during the COVID-19 pandemic, where technology has become necessary in carrying out activities. ICT plays roles in human life, including communication, finding information, education, transportation, tourism, finance, and business. In modern life, which is synonymous with high business activity, technology at work, changes in the pattern of collaboration with the government, social interaction in society, impact macroeconomic growth, and people's living standards (Mandilas et al., 2013; Roztocki et al., 2019). The contribution of ICT in various aspects of life includes improving social and economic welfare, education, services and health. Socio-economic development shows the dimensions of society, technology, business, and government policies. The change in public transactions is known as a cashless society in making people aware of noncash instruments. Most people still use cash transactions, and some still use non-cash. Economic activities use information technology to facilitate the communities in online shop transactions, transfers, or purchases and bills through credit cards or debit banks (Roztocki et al., 2019; Wijayanto et al., 2019). An organization can apply iinformation technology effectively and efficiently if individuals in the organization apply it with the help of internet technology. The Internet changes behavior, including the payment instruments, from metal to conventional paper money and electronic instruments (Umar \& Idris, 2018). This change can happen because the Internet can connect more widely to many people, such as communities, organizations, business actors, and companies. In addition, nowadays, people can access the Internet anywhere and anytime. Indonesia is ranked first in the $10^{\text {th }}$ largest e-commerce growth with 78 per cent growth (Aribowo, D. P., \& Nugroho, 2013). This condition shows that the electronic trading business has good economic value, so business actors must utilize it, including the SME sector. Many 
enterprises use social media as a potential place to sell or buy products. Businesses such as the businessto-consumer type or consumer-to-consumer type have used online media as a market to sell their products (Rahayu \& Baridwan, 2020).

Opportunities for the development of e-commerce information technology are very open in Indonesia (Herlan \& Yono, 2016; Nizar, 2017). One of the reasons is because of the large population so that it becomes a broad market potential. The number of internet users in Indonesia certainly cannot be denied that it can also encourage business ventures to be more advanced and develop. Internet users are not limited to utilizing information, but they can also use it to conduct buying and selling transactions of goods. Like the current Covid-19 pandemic, the Internet makes distance, time, and cost limitations easily overcome. Enterprises can increase business, marketing, and purchasing products by using Electronic Commerce (E-Commerce). The complexity of business transactions (commercial) starts from sales, marketing and distribution activities from producers to consumers using digital technology on the Internet and the web, known as e-commerce (Dachyar \& Banjarnahor, 2017; Roztocki et al., 2019). The existence of e-commerce greatly helps SMEs that are already using technology. E-commerce services are increasingly being used by the public, especially SMEs, during the current COVID-19 pandemic. The reason is that this service provides convenience for SMEs and the people in conducting buying and selling goods and other financial transactions. Users of Accounting Information Systems (AIS) also get some additional flexibility from e-commerce; transactions using e-commerce also provide several psychological, legal, and economic problems. These problems include: 1) Many SMEs still do not understand the ease of transacting using ecommerce because of limitations in information. 2) SME actors who do not understand e-commerce products will discourage their interest in using e-commerce product services, so many SMEs prefer to transact directly. 3) There is an attitude of distrust of SMEs in the transaction system using e-commerce. 4) SMEs are afraid of the risks involved when using e-commerce services, including the risk of concerns about fraud.

The Technology Acceptance Model is one of the grand theories that underlie research on the use of information technology. TAM is a theoretical model to determine the level of acceptance of a new technology system among information technology users (Ali et al., 2020; Malonda et al., 2020). TAM is used as a representative who can explain the reasons for the implementation of technology by individuals and organizations based on the influence of two cognitive factors, namely perceived usefulness and perceived usability. Several studies on e-commerce show that trust can affect interest in using e-commerce, such as shopping or selling goods online. A study shows trust's influence on the interest in online transactions. The study used a sample of students from the Faculty of Economics, UNY (Aribowo \& Nugroho, 2013). Higher trust makes someone feel more interested in conducting online transactions based on the accuracy of expectations with the expected results of online transactions. Perception of user convenience is an individual's assumption that using technology will not expend more effort or, in other words, that using technology does not complicate the work (Davis, 1986). Every technology is created to facilitate the activities of each individual. The easier it is to use technology; the more individuals are interested in using it. According to the initial observations of researchers on SMEs in Klungkung District, users of e-commerce service products find it difficult to use applications from e-commerce products. This difficulty is also why SMEs do not use e-commerce service products because they believe transacting using e-commerce services is more complicated than transacting directly. As we know, many e-commerce service applications, such as Lazada, Tokopedia, Shopee, and others, are helpful for everyday life, but SMEs rarely use them. Technology users should be familiar with digital life and not experience difficulties in operating it. Risk is an uncertainty felt by the user that causes harm to the user. The risk initially perceived by the user is the risk of cybercrime (Nizar, 2017). Cybercrime can threaten every transaction made by consumers. The security of each user's data also does not escape the threat of this cybercrime. The risk can harm users, and the developers themselves should increase the safety of their system and provide education to potential users to minimize the occurrence of errors that harm users. Stakeholders can reduce the risk with mutually beneficial policies.

\section{METHODS}

The locations of this research are Klungkung, Denpasar, and Buleleng Districts, especially small and medium weaving enterprises (SMWE) registered with the Cooperatives and SMEs and Trade Offices by distributing questionnaires to women entrepreneurs of SMEs. The research conduct at those locations because the SMEs had received e-business-based online marketing training that was beneficial for them. However, some SMWEs are reluctant to use e-business services on the pretext that it is difficult to understand or afraid of being deceived. There is a sense of doubt in the use of e-business, and many more fears, including security risks in transactions using e-business services. This research used a quantitative descriptive approach 
The primary data of the research was collected using a questionnaire. In contrast, the secondary data included information related to the general description of the subject and the research location, the characteristics of the respondents, as well as other relevant data. The data obtained were analyzed to determine the quality of the data, then tested the classical assumption was and tested the hypothesis using multiple linear regression. The population in this study were SMWEs in Klungkung District, Denpasar, and Buleleng Regency. The number of SMWEs using e-business in 2021 is 43, which women manage. The method used in determining the sample in this study is saturated sampling. The criteria used as a reference for sampling are: (1)The sample is Small and Medium Enterprises in Klungkung, Denpasar, and Buleleng Districts; (2) Samples are familiar with Online Shop, E-Commerce, and Marketplace; (3) The sample has made online transactions at least one time. This type of data is quantitative by asking respondents for answers on perceptions of usability and risk of interest in using e-business at SMWEs. The results of the questionnaire in the form of responses from respondents were measured using a Likert scale. Primary data was measured using a Likert scale. Secondary data in this study are the names of SMWEs in Klungkung District, Buleleng Regency, and Denpasar. We obtained the data from the Office of Cooperatives, Small and Medium Enterprises, and Trade. The questionnaire distribution was sent to selected respondents. The respondent fills out this questionnaire with personal information or things that the respondent knows. We also collected data from journals, books, and previous research that contained information or data related to research.

The observation method is one way of collecting research data on SMWEs business actors. This method can be observed directly associated with the phenomena that exist at the research location and the required data. In simple terms, observation is the process of researchers in looking at the research situation. Tools used in observations are observation sheets, checklists, event records, and others. In this case, the researcher directly visited the SMWEs, which was determined through the sample criteria to distribute the questionnaire. The results of this observation become a source of data for researchers to obtain data in taking research samples. Through searches conducted regarding research samples, there were 43 SMWEs primarily managed by women. The questionnaire's preparation uses vital indicators built from relevant theories and then compiles a closed questionnaire in the form of structured questions for each variable. Then the results of the data will be analyzed to be used as a reference in research. We collect data using a Questionnaire for Small and Medium Enterprises to see how SMWEs views their interest in E-Commerce services. The questionnaires were distributed directly to the field by complying with the Covid-19 health protocol. In calculating the questionnaire, the researcher used a 5-point Likert scale. We conducted a literature study by collecting data and theories relevant to the problems, including relevant articles, journals, books, and previous research. This study contains three research instruments, usability and the risk of interest in using e-commerce. Each instrument consists of several questions or statements with a scale of 1-5 (Likert).

Perception of usefulness is how a person selects, receives, manages and conveys information sourced from the environment. (Herlan \& Yono, 2016). Usability reflects an individual's belief in reducing the burden of completing work using technology assistance (Harlan, 2014). E-business users think that ebusiness services are more flexible, easy to understand, uncomplicated, easy to learn, and easy to operate as characteristics of user convenience. (Rahayu, 2018) used several indicators to measure the perceived usability of the system: easy to learn and flexible in use, the system can easily do what the user wants, easy to use and time-efficient, and easy to operate. Risk perception is a perception of uncertainty and unintended consequences of using all things related to goods and services (Rahayu, 2018). Risk Perception explains the transaction security risk and uncertainty about the goods or products ordered. There are several indicators of risk perception variables, including product risk, transaction risk, psychological risk (Mauludiyahwati, 2017). Interest is a person's desire to do a specific behavior (Rahayu, 2018). Interest is a tendency to have involvement in something relatively permanent to pay more attention and remember continuously, followed by a sense of pleasure to achieve satisfaction using technology. There are several indicators of interest in the use of e-business, including according to needs, benefits, accuracy in product purchases, repeat purchases (Mauludiyahwati, 2017).

We used statistical analysis methods for data collection by distributing 43 questionnaires filled out by SMWEs in three areas that conducted online business transactions using e-business. The descriptive statistical analysis method in this study aims to describe the research variables, namely User Ease of Interest in Transactions Using E-business in SMWE $\left(\mathrm{X}_{1}\right)$ and Risks $\left(\mathrm{X}_{2}\right)$ on Interest in Transactions Using Ebusiness in SMWE (Y). Description statistical analysis includes explaining groups through maximum values, minimum values, averages (means), and standard deviation variations. (Sugiyono, 2011). A valid instrument to measure what should be measured to obtain data (Sugiyono, 2011). The measurement of the accuracy of the questionnaire items used is through a validity test. The results are declared valid if they meet the required significance level by looking at the Pearson correlation value. If the significant value is $<$ 
$0.05(5 \%)$, then the instrument is valid. However, if $>0.05(5 \%)$, it is invalid (Sugiyono, 2011). A reliable instrument is an instrument that The level of reliability using measurements of the object (Ghozali, 2011). A questionnaire instrument will meet the reliable requirements if it can produce the same data consistently on the same research object. The conditions that are completed are the Cronbach Alpha Coefficient value $\geq$ 0.60 .

Testing for multicollinearity is seen in the tolerance value and Variance Inflation Factor, which also has specific detection requirements that must be met. Tolerance measures the independent variables used in research that other variables cannot explain. Hence, the tolerance value is inversely proportional to the VIP value. We use these measurements by interpreting one independent variable with other independent variables (Ghozali, 2011). If a regression model free from multicollinearity has a VIF value of less than or not more than ten and a tolerance value of not less than 0.1 , then multicollinearity symptoms occur. The heteroscedasticity test is a reference for the regression model used, using the Glejser test. Multiple linear regression examines the effect of several independent variables on a dependent variable. We then interpret the results in the discussion. The coefficient of determination (R2) describes the amount of variation that the independent variable can explain. In the partial test, analyze the effect of the independent variable on the dependent variable by also testing the level of significance. If $t$-count $<\mathrm{t}$-table with a significant 0.05 so $\mathrm{H}_{0}$ is accepted, then variable $\mathrm{X}$ does not affect variable $\mathrm{Y}$ and vice versa if $\mathrm{t}$-count $>$ from $\mathrm{t}$-table with significant 0.05 so $\mathrm{H}_{0}$ is rejected then variable $\mathrm{X}$ affects variable $\mathrm{Y}$.

\section{RESULTS AND DISCUSSIONS}

\section{Results}

The questionnaires collected during the research were as many as 43 pieces. Questionnaires can be processed and analyzed with a useable response rate of $100 \%$. The characteristics representing the respondents' criteria based on age, education level, and the type of e-business service used through data collection-overall described in Table 1.

Table 1. Characteristics of Respondents

\begin{tabular}{|c|c|c|c|c|}
\hline No & Description & Information & Frequency & Percentage (\%) \\
\hline \multirow{5}{*}{1} & \multirow{5}{*}{ Age } & $25-35$ & 8 & 15.27 \\
\hline & & $36-45$ & 9 & 23.26 \\
\hline & & $46-55$ & 14 & 39.21 \\
\hline & & $>55$ & 12 & 22.26 \\
\hline & & & & 100 \\
\hline \multirow{5}{*}{2} & \multirow{5}{*}{ Education } & Elementary School & 7 & 18.60 \\
\hline & & Junior/Senior High School & 19 & 41.86 \\
\hline & & Diploma/Bachelor & 14 & 37.22 \\
\hline & & Master's & 3 & 2.32 \\
\hline & & & & 100 \\
\hline \multirow{4}{*}{3} & \multirow{4}{*}{$\begin{array}{c}\text { E-business services } \\
\text { used }\end{array}$} & Online Shop & 36 & 85.37 \\
\hline & & E-commerce & 4 & 8.97 \\
\hline & & Marketplace & 3 & 5.66 \\
\hline & & & & 100 \\
\hline
\end{tabular}

The specifications on the characteristics of the respondents indicate in terms of age were dominated by 46-55 years old respondents. Weaving crafts require perseverance because the process is complicated, and most of it is a hereditary effort from parents. Based on the respondent's latest education, dominated by junior high school or high school, the SMWE in their development requires skills in their efforts to survive. Reviewed from the e-business services used, most respondents use online shops $(85.37 \%)$. The number shows that online shop services are the most widely used by respondents. We tested the validity using the Pearson's Correlation correlation technique in SPSS 24.0 (Ghozali, 2011). The results of validity test is presented in Table 2 . 
Table 2. Results of Validity Test

\begin{tabular}{|c|c|c|c|c|c|}
\hline No. & Variable & Item & $\begin{array}{c}\text { Pearson's } \\
\text { Correlation } \\
\end{array}$ & Sig & Alpha Cronbach \\
\hline \multirow[t]{3}{*}{1} & Usability & $\mathrm{X}_{1.1}$ & 0.792 & 00,000 & 0.750 \\
\hline & & $\mathrm{X}_{1} .2$ & 0.783 & 00,000 & \\
\hline & & $\mathrm{X}_{1} .3$ & 0.798 & 00,000 & \\
\hline \multirow[t]{3}{*}{2} & Risk perception & $\mathrm{X}_{2.1}$ & 0.810 & 00,000 & 0.820 \\
\hline & & $\mathrm{X}_{2.2} 2$ & 0.893 & 00,000 & \\
\hline & & $\mathrm{X}_{2.3}$ & 0.644 & 00,000 & \\
\hline \multirow[t]{3}{*}{3} & Interest in using e-business & Y.1 & 0.697 & 00,000 & 0.822 \\
\hline & services & Y.2 & 0.676 & 00,000 & \\
\hline & & Y.3 & 0.688 & 00,000 & \\
\hline
\end{tabular}

The description of the research variables includes the results of descriptive analysis, including the minimum score, maximum score, average, and standard deviation. Table 3 describes the variable score of usability, risk perception, and interest in using e-business services.

Table 3. Results of Descriptive Analysis

\begin{tabular}{lcccc}
\hline \multicolumn{1}{c}{ Variable } & $\mathbf{X}_{\mathbf{1}}$ & $\mathbf{X}_{\mathbf{2}}$ & $\mathbf{Y}$ & $\begin{array}{c}\text { Unstandardized } \\
\text { Residual }\end{array}$ \\
\hline Minimum & 24 & 38 & 12 & \\
Maximum & 35 & 50 & 25 & \\
Averages & 30.84 & 43.84 & 20.56 & \\
Deviation Standard & 2.84 & 3.49 & 2.88 & \\
$\mathrm{~N}$ & & & & 43 \\
Test Statistic & & & & 0.102 \\
Asymp. Sig. (2-tailed) & & & & 0.200 \\
Tolerance & 0.783 & 1.278 & & \\
VIF & 0.702 & 1.473 & & \\
Heteroscedasticity & & & & \\
$T$ & 1.393 & 0.171 & & \\
Sig. & 1.203 & 0.236 & & \\
Unstandardized Coefficients & 0.569 & 0.075 & & \\
$T$ & 2.287 & -0.323 & & \\
Sig & 0.028 & 0.040 & & \\
Adjusted R Square & & & & \\
\hline
\end{tabular}

Based on Table 3, usability data shows that the average value is close to its maximum value, so the user comfort response does not vary. Most of the respondents' answers answered on indicators stating that the operation of e-commerce services is effortless to use so that orders can be processed automatically quickly; The risk perception data has a maximum score of the distribution of perceived risk closer to the average score, which indicates that the response to perceived risk does not vary. Respondents gave answers with the highest scores on the statement items; respondents felt uncomfortable when e-commerce provided information that caused many unexpected problems; Data on interest in using e-business services has a distribution of the maximum value close to the average score, which indicates that the response to interest in using e-business services does not vary. Most of the respondents stated that they strongly agree with the indicators of interest in using e-commerce services because they provide valuable and accessible information for buyers.

The Kolmogorov-Smirnov One-Sample test shows the distribution of data from the effect of unstandardized residuals from perceived usability and perceived risk on interest in using e-business services. The test results table reveals the significance value of 2 -tailed $>0.05$ for Kolmogorov-Smirnov $\mathrm{Z}$ statistic with normal data distribution. In the multicollinearity test, the variance inflation factor value is < 10 and > than 0.10; in other words, the correlation between independent variables is weak. This result 
shows that there is no correlation between the independent variables in this research model. The regression model also shows no residual variance equation from one observation to another as a condition of the Glejeser test for heteroscedasticity. Then the resulting regression model can be said to be good with a significance value $>$ of 0.05 . So, we can conclude that the regression model used does not have any symptoms of heteroscedasticity. Based on the multiple linear regression analysis results, an equation of the regression line uses constant analysis and beta coefficients. The partial testing uses the following equation.

$$
\begin{aligned}
& Y=\alpha+\beta_{1} X_{1}+\beta_{2} X_{2}+\varepsilon \\
& Y=3,863+0,569 X_{1}-0,075 X_{2}+\varepsilon
\end{aligned}
$$

Based on the regression model formed, the results are: The constant 3,863 shows that if the variables of Usability $\left(\mathrm{X}_{1}\right)$ and risk perception $\left(\mathrm{X}_{3}\right)$ are constant, the variable interest in using e-business services $(Y)$ has a positive value of 3,863 units; Usability $\left(\mathrm{X}_{1}\right)$ has a regression coefficient of 0,569 . A positive regression coefficient value indicates that user convenience $\left(\mathrm{X}_{1}\right)$ positively affects the interest in using ebusiness services $(\mathrm{Y})$. Hence, increasing user ease $\left(\mathrm{X}_{1}\right)$ can increase interest in e-business services $(\mathrm{Y})$ by 0,569 , assuming that the other independent variables are fixed; Risk perception $\left(X_{2}\right)$ has a regression coefficient of 0,075 . A negative regression coefficient value indicates that the perception of risk $\left(\mathrm{X}_{3}\right)$ reduces the interest in e-commerce services $(\mathrm{Y})$. Hence, any increase in risk perception $\left(\mathrm{X}_{3}\right)$ can reduce the interest in using e-business services $(\mathrm{Y})$. The value is 0.075 , so that we assume that the influence of other variables is fixed. Results of the analysis show that the coefficient of determination is 0,396 . The coefficient indicates that user convenience and risk perceptions influence $39,6 \%$ of the variables of interest in using e-business services, while the other factors influence $60,4 \%$.

\section{Discussion \\ The Effect of Usability on Interest in Using e-Business Services}

We test the first hypothesis in this study regarding the effect of usability on interest in using ebusiness services. The results show that the regression coefficient is 0.569 , and the significance level is 0.028 . This value is less than the maximum required limit (0.05). Hence, we can conclude that the perception of usability positively affects an interest in using e-business services. Therefore, the first hypothesis is accepted. The results in usability perception affect the interest in using e-business services. Consumer perceptions of usability can lead to an interest in using e-business services. If the usability is higher, the interest in using e-business services will be higher. Previous study supported the results of this study that with the usability getting higher, it can be used as a measure to grow someone's interest in using e-business services (Triandini et al., 2013). With the usability, individuals will find it easier to understand and get information in using e-commerce. In addition, the use of an easy-to-use information system can speed up work and will be much more flexible with the ease and convenience offered by e-commerce services. On the other hand, if it is difficult to use these services, the interest in using e-commerce services will decrease. Several empirical studies also supported findings of the significant effect of user convenience on behavioral interest in using e-commerce (Triandini et al., 2013). User convenience positively affects behavior (Dachyar \& Banjarnahor, 2017; Saputri, 2020). In line with that, user convenience has positive effects (Budiastuti, A. D., \& Muid, 2020; Shomad \& Purnomosidhi, 2016). Hence, the implementation of e-business will become easier if business actors have adequate understanding and skills about digital technology (Alam et al., 2011; Rodrigues et al., 2016; Sarli Rahman \& Yusrizal., 2020).

\section{The Effect of Risk Perception on Interest in using e-business Services}

The results of testing the second hypothesis in research on the effect of risk perception on interest in using e-business services show that the regression coefficient value has a negative direction of 0.075 with a t-test significance value less than 0.05 , where the significance level is 0.040 . Hence, the second hypothesis is accepted. The risk perception reduces interest in using e-business services. If the perception of risk is higher, the interest in using e-business services will be lower. The analysis in this study shows that the perception of risk hurts the interest in using e-business services. Hence, every risk faced by SMWEs can affect the interest in using e-business services. The risks faced by e-business users are transaction security and the uncertainty of the goods ordered. Risk perception will reduce the individual's intention to use the online store. This prediction arises based on logic, if the higher risk causes someone to fear when transacting online, and vice versa. If the perception of low risk will cause someone not to feel afraid in conducting online transactions, it is undeniable that they will return to conduct online transactions in the future. The perception of risk is a perception of the uncertainty and unintended consequences of using a product or service (Rahayu, 2018). This study is consistent with the empirical findings revealed that risk perception reduces interest in using e-commerce (Shomad \& Purnomosidhi, 2016). The same results were also shown 
that risk had a significant influence on buyers' interest in using e-business (Caldwell et al., 2013; Ghobakhloo \& Tang, 2013; Grant et al., 2014; Mandilas et al., 2013; Utami \& Suwarno, 2017).

\section{CONCLUSION}

This research implies e-business application developers will continuously innovate to create userfriendly e-business applications. These applications will improve the perception of women SMWEs towards e-business services. Those services must be easy to learn and flexible in use, easily do what they want, timeefficient, and easy to operate. Thus, we hope that the interest in using e-business services will increase. In addition, e-business application developers create secure e-business applications to minimize the risk of using e-business. A secure e-business application will improve the perception of SMEs towards e-business services on a low level of risk, have transaction security, system security is excellent, and make transactions convenient. Thus, we hope that the interest in using e-business services will increase. SMWEs in Klungkung District, Buleleng Regency, and Denpasar need the usability and risk perception on e-business services so that the perception of SMWE actors towards e-business services is getting better. SMWE actors need ebusiness services that are easy to learn and flexible to use, convenient, time-efficient, easy to operate, have a low-risk level, secure and comfortable, and increase motivation. Further research should use a more comprehensive research location and different analytical methods to make the study results related to this topic more valid and complete.

\section{REFERENCES}

Adryanto, R. (2016). Pengaruh Kepercayaan, Persepsi Manfaat dan Persepsi Kemudahan Pengguna Terhadap Minat Beli di Toko Online. Universitas Yogyakarta, 19-26.

Ahmadi, C., \& Hermawan, D. (2013). E-Business \& E-Commerce. Andipublisher.

Alam, S. S., Ali, M. Y., \& Jani, M. F. M. (2011). An Empirical Study Of Factors Affecting Electronic Commerce Adoption Among Smes In Malaysia / Veiksnių, Turinčių Įtakos Elektorinei Prekybai, Studija: Malaizijos Pavyzdys. Journal of Business Economics and Management, 12(2), 375-399. https://doi.org/10.3846/16111699.2011.576749.

Ali, R. M., Afzal, M. I., \& Mahomed, A. S. B. (2020). The Role of Technology Acceptance Model on WhatsApp's Official Usage in Malaysian HEIs. International Journal of Precision Technology, 8(5), 270-273. https://doi.org/10.35940/ijrte.D9725.018520.

Anisah, L. (2019). Analisis Faktor-Faktor Yang Memperngaruhi Penggunaan Website dan Aplikasi Shopee untuk Berbelanja Online Pada Mahasiswa Universitas Sanata Dharma. 9-40.

Aribowo, D. P., \& Nugroho, M. A. (2013). Pengaruh Trust dan Perceived of Risk Terhadap Niat Untuk Bertransaksi Menggunakan E-Commerce. Nominal Barometer Riset Akuntansi Dan Manajemen, 2(1).

Biucky, S. T., Abdolvand, N., \& Harandi, S. R. (2017). The Effects Of Perceived Risk On Social Commerce Adoption Based On The Tam Model. International Journal of Electronic Commerce Studies, 8(2), 173-196. https://doi.org/10.7903/ijecs.1538.

Budiastuti, A. D., \& Muid, D. (2020). Analisis Faktor-faktor Pengaruh Minat Penggunaan Sistem Informasi Akuntansi Berbasis E-Commerce Pada Aplikasi Shopee Dengan Menggunakan Technology Acceptance Model (TAM). Diponegoro Journal of Accounting, 9(4), 1-10.

Caldwell, N., Harland, C., Powell, P., \& Zheng, J. (2013). Impact of e-business on perceived supply chain risks. Journal of Small Business and Enterprise Development, 20(4), 688-715. https://doi.org/10.1108/jsbed-12-2011-0036.

Chan, F. T. S., Yee-Loong Chong, A., \& Zhou, L. (2012). An empirical investigation of factors affecting ecollaboration diffusion in SMEs. International Journal of Production Economics, 138(2), 329-344. https://doi.org/10.1016/j.ijpe.2012.04.004.

Chin, L. P., \& Ahmad, Z. A. Bin. (2015). Perceived Risk As An Extension To TAM Model: Consumers' Intention To Use A Single Platform E-Payment. Australian Journal of Basic and Applied Sciences, 9(2), 323330.

Cho, Y. C., \& Sagyn, E. (2015). Exploring Factors That Affect Usefulness, Ease Of Use, Trust, And Purchase Intention In The Online Environment. International Journal of Management \& Information Systems, 19(1), 21-36.

Dachyar, M., \& Banjarnahor, L. (2017). Factors influencing purchase intention towards consumer-toconsumer e-commerce. Intangible Capital, 13(5), 946-966. https://doi.org/0.3926/ic.1119.

Darmayanti, N. P., Purnamwati, I. A., \& Prayudi, M. A. (2017). Pengaruh Pendekatan TeChnology Acceptance Model dan Faktor Sosial Terhadap Penerapan Sistem Informasi Keuangan Daerah Pada SKPD di 
Kabupaten Gianyar. E-Journal S1 Ak Universitas Pendidikan Ganesha, 8(2), 1-12.

Davis, F. D. (1986). Perceived Usefulness, Perceived Ease of Use and User Acceptence of Information Technology. MIS Quarterly, 13(5), 319-339.

Farzianpour, F., Pishdar, M., Shakib, M. D., \& Toloun, M. R. S. H. (2014). Consumers' Perceived Risk And Its Effect On Adoption Of Online Banking Services. American Journal of Applied Sciences, 11(1), 47-56. https://doi.org/10.3844/ajassp.2014.47.56.

Ghobakhloo, M., \& Tang, S. H. (2013). The role of owner/manager in adoption of electronic commerce in small businesses the case of developing countries. Journal of Small Business and Enterprise Development, 20(4), 754-787.

Ghozali, I. (2011). Aplikasi Analisis Multivariate dengan Program IBM SPSS 19 (B. P. U. Diponegoro (ed.)).

Ghozali, Imam. (2011). Aplikasi Analisis Multivariate Dengan Program IBM SPSS 19 (5th ed.). Badan Penerbitan Universitas Diponegoro.

Grant, K., Edgar, D., Sukumar, A., \& Meyer, M. (2014). "Risky business": Perceptions of e-business risk by UK small and medium sized enterprises (SMEs). International Journal of Information Management, 34(2), 99-122. https://doi.org/10.1016/j.ijinfomgt.2013.11.001.

Hamdani, A. (2020). Pengaruh Lingkungan Keluarga, Pengetahuan, Kewirausahaan, Ekspektasi Pendapatan dan E-Commerce Terhadap Minat Berwirausaha Mahasiswa Akuntansi.

Harlan, D. (2014). Pengaruh Kemudahan Pengguna, Kepercayaan dan Resiko Persepsian Terhadap Minat Bertransaksi Menggunakan E-banking pada UMKM di Kota Yogyakarta. 13-37.

Herlan, \& Yono. (2016). Pengaruh Persepsi Kemudahan, Penggunaan, Persepsi Kegunaan dan Pengalaman Terhadap Minat Wajib Pajak Menggunakan Sistem E-Filling. Accounting Journal, 5(2).

Laudon, K., \& Laudon, J. (2014). Management Information Systems (13 ed.). England: Pearson: amanaging the digital frms.

Malonda, R. C., Tulung, J. E., \& Arie, F. F. (2020). The Effect Of Technology Acceptance Model, Perceived Trust, Security, And Attitude Toward Ovo Usage. Jurnal EMBA: Jurnal Riset Ekonomi, Manajemen, Bisnis Dan Akuntansi, 8(1), 401-410.

Mandilas, A., Karasavvoglou, A., Nikolaidis, M., \& Tsourgiannis, L. (2013). Predicting Consumer's Perceptions in On-line Shopping. Procedia Technology, 8, 435-444.

Mauludiyahwati, S. (2017). Pengaruh Kepercayaan, Keamanan, Kualitas Pelayanan dan Persepsi Resiko Menggunakan E-commerce Terhadap Keputusan Pembelian Online.

Nizar, M. A. (2017). Teknologi keuangan: Konsep dan Implementasi di Indonesia. Warta Fiskal Edisi V, Kementrian Keuangan.

Rahayu, R. W. (2018). Pengaruh Persepsi Manfaat, Persepsi Kemudahan, Persepsi Risko, dan Inovasi Teknologi Terhadap Aplikasi Go Pay Dari PT. Gojek Indonesia.

Rahmadi, H., \& Malik, D. (2016). Pengaruh Kepercayaan dan Persepsi Risiko Terhadap Keputusan Pembelian E-commerce pada Tokopedia.com di Jakarta Pusat. Reformasi Administrasi, 3(1), 126145.

Rahman, A., \& Dewantara, R. Y. (2017). Pengaruh kemudahan Pengguna dan Kemanfaatan Teknologi Informasi Terhadap Minat Menggunakan Situs Jual Beli Online. Jurnal Administrasi Bisnis, 5(1).

Rahmawati, Y. D., \& Yuliana, R. (2020). Pengaruh Persepsi Manfaat, Persepsi Kemudahan, dan Persepsi Keamanan Terhadap Keputusan Pengguna E-Wallet pada Mahasiswa Stie Bank BPD Jateng. Journal of Economics and Banking, 159.

Rodrigues, L. F., Oliveira, A., \& Costa, C. J. (2016). Playing seriously - How gamification and social cues influence bank customers to use gamified e-business applications. Computers in Human Behavior, 63, 392-407. https://doi.org/10.1016/j.chb.2016.05.063.

Roztocki, N., Soja, P., \& Weistroffer, H. R. (2019). The role of information and communication technologies in socioeconomic development: towards a multi-dimensional framework. Information Technology for Development, 25(2), 171-183. https://doi.org/10.1080/02681102.2019.1596654.

Saputri, R. (2020). Pengaruh Kepercayaan, Risiko Belanja dan Kemudahan Bertransaksi Terhadap Bertransaksi Daring (Online) di Tokopedia.

Sarli Rahman, F., \& Yusrizal., S. (2020). Perceptions Of E-Customers For E-Business: Effects Of Covid-19 On Online Food Customer Perception Who Buys Through The E-Transportation Application. Journal of Archaeology of Egypt/Egyptology, 17(7), 6836-6855.

Shomad, A. C., \& Purnomosidhi, B. (2016). Pengaruh Kepercayaan, Persepsi Kegunaan, Persepsi Kemudahan dan Persepsi Risiko Terhadap Penggunaan E-Commerce. Jurnal Ilmiah Mahasiswa FEB Universitas Brawijaya, 1(2).

Sugiyono. (2014). Metode Penelitian Kuantitatif Kualitatif Dan R\&D. Alfabeta.

Triandini, E., Djunaidy, A., \& Siahaan, D. (2013). Factors Influencing E-Commerce Adoption by SMES Indonesia: A Conceptual Model. Lontar Komputer, 4(3), 301-311. 
Umar, T. I., \& Idris, M. (2018). Influence of Social Media on Psychosocial Behaviour and Academic Performance of Secondary School Students. Journal Of Education \& Entrepreneurship, 5(2), 36-46. https://doi.org/10.26762/jee.2018.40000013.

Utami, A. D., \& Suwarno, A. E. (2017). Pengaruh Kepercayaan, Kemudahan, Manfaat, dan Resiko terhadap Minat Pembeli Untuk Menggunakan Sistem E-Commerce.

Wijayanto, G., Suryana, Y., Oesman, Y. M., \& Helmi, A. (2019). The Influence of Self-concept in Using Credit Card on its Decision to Use. Journal of Management Information and Decision Sciences, 22(1), 1-10.

Wikarsa, L., \& Angdresey, A. (2021). Using Technology Acceptance Model to Evaluate the Utilization of Kolintang Instruments Application. Jurnal Pekommas, 6(1), 33-41. https://doi.org/10.30818/jpkm.2021.2060104.

Yolanda, A., \& Widijoko, G. (2016). Pengaruh Persepsi Manfaat, Persepsi Kemudahan, Persepsi Kenyamanan dan Norma Subjektif Minat Menggunakan Electronic Commerce(E-commerce). Jurnal Ilmiah Mahasiswa FEB Universitas Brawijaya, 2(2), 1-20. 